chief was erroneously awarded the responsibility for statements, compared to which those cited in the previous article were empty nonentities. My exoneration was quite complete.

When a reporter receives an assignment and fails, he faces the danger of losing his job. We are not concerned with that contingency, but we ought to be concerned with what might result from the pressure of circumstances. Either a flat refusal to release any information whatsoever or failure to supply adequate information nearly always results in the type of article which leaves the public in considerable doubt as to any justification for archaeological research. Controlled popularization can produce highly desirable results. It offers an avenue through which the pot-hunter and the public in general may acquire a greater appreciation of prehistory; it can encourage school children to search for village sites and gather surface collections; it can cause numerous individuals to submit reports concerning archaeological evidence encountered to the institution sponsoring the articles and, finally, much can undoubtedly be accomplished by way of arousing a greater appreciation for the meaningless objects displayed in museum cases.

There is much advantage to be gained by calling the same reporter whenever a release is to be made. In his eagerness to obtain further releases, he will hold his imagination under control. There should always be a definite agreement that the final article be submitted for the informant's approval before it goes to press. Obviously, any information or photographs which are apt to incite the looting of graves by curious individuals should not be included.

$$
\begin{aligned}
& \text { T. M. N. LEwis } \\
& \text { University of Tenneseee } \\
& \text { Knoxville, Tennessee }
\end{aligned}
$$

\title{
Former Indian Sites in Maryland, as Located by EARLy COLONIAL RECORDS
}

Dr. D. S. Davidson's interesting article in American Antiquity, Volume I, No. 2, has encouraged me to submit certain references pertaining to the Indians of Maryland which have come to my attention. Concerning the Conoy Indians (Piscattaways) Mr. Davidson says (p. 85): "For the Conoy of Maryland ... there seem to be no direct accounts of treatment of the dead."

Searching for evidence on this subject is indeed like looking for the proverbial needle in a haystack. A solitary record is the reward of long research. In the month of August, 1678, Nicotagsen, then Emperor of Piscattaway, together with the "speaker" of that people and other Indian notables, presented himself to Lord Baltimore's Council, then in session, on a matter of business. When questioned as to why some of their chiefs absented themselves from this meeting, the Piscattaways offered the following excuse: "Most of their great men 
were very busie in gathering together their dead bones." 41 This remark undoubtedly has reference to a burial custom.

Dr. Davidson refers to a protest submitted to the (Maryland) authorities in the year 1686 by the "Nanticokes at Assateague." against certain English persons who were charged with having vandalized the tombs of the Indian kings and with having stolen from these tombs quantities of "roanoke and skins" (p. 86, note 6). He refers to MacLeod, whose work I have not consulted. There is no doubt in my mind as to the identity of the original record on which these remarks are ultimately based; but inasmuch as this record has a sense quite different from that which Dr. Davidson, quoting MacLeod, appears to attribute to it, I am led to infer that the latter has not quoted it in full. This record is entered in the proceedings of the Council of Maryland and bears date May 6 th, 1686. It reads as follows:

"The King of Assateague complaines that severall of the Inglish . . . (naming five) . . . were come and seated among them in the very Towne where they live ... (referring to Quaponqua or Copomco Indian Town, which was situated on Pocomoke River, northwest of the site of the modern village of Newark, in Worcester County, Md.) ... but particularly he complaineth against Edward Hamond for that whereas it is a custom among them upon the death of an Indian King to save his bones and make a case with skinns wherein they inclose the bones and fill it up with Ronoke (sic), and other their riches, he the said Hamond about a month since had upon like occasion of one of their kings dyeing stolen away the skinns and roanoke from the place where he was layd," etc. ${ }^{42}$

The Assateagues inhabited the seaboard side of the eastern shore of Maryland in early historical times. It is not unlikely that they were related to the Nanticokes and had similar language and customs; but politically they were treated both by Maryland and by Virginia as a separate people. War was made on them by Virginia in 1659 , and it is probable that the two towns which they are known to have lived in later in the century were places of refuge, not their original home. Those Indians who, some time before 1705, settled at the head of Indian River, in what is now Sussex County, Delaware, where a reservation was laid out for them in 1711 , for which a Maryland patent was soon afterwards obtained, are identifiable as a band of Assateagues, in which there had entered an admixture of other Indian strains, among which an element of Choptank is discernible. After 1705 and until the middle of the eighteenth century, after which we hear no more of them, they are mentioned in Maryland records under the name of Indian River Indians. The site of their reservation is on the head of Indian River and on the southern side of the river, and it is certainly not

${ }^{41}$ Maryland Archives, Vol. XV, p. 185; see also my article on Piscattaway in the Maryland Historical Magazine, Vol. XXX, No. 3, p. 190.

${ }_{42}$ Maryland Archives, Vol. V, p. 480 ; referred to in my article on Piscattaway, Md. Historical Magazine, Vol. XXX, No. 3, p. 191. 
far from the place where the so-called "Nanticokes" are now living. All of it, however, was disposed of before 1744, and what thereafter became of these Indian River Indians is a mystery, since it was not long after this that Maryland had no further concern with their destiny.

I suspect that the modern "Nanticokes" are their direct descendants. I should add, however, that I have received from $\mathrm{Mr}$. A. Crozier, President of the Archaeological Society of Delaware, a piece of information which tends to modify this theory. Among these "Nanticokes" of today Mulberry is a family name. This was the outstanding family name of that remnant of the Choptanks living at Locust Neck Town, on Choptank River above Cambridge, during the latter half of the eighteenth and the beginning of the nineteenth century.

Dr. Davidson alludes to a Nanticoke custom of mummifying the bodies of chiefs and of preserving the mummies in "temples" constructed for that purpose, "probably much the same as in Virginia." He quotes MacLeod as saying in substance: "In Dorsetshire, Maryland ... (this can mean only Dorchester County, which lies along the southern shores of Choptank River) . . . the 'body' of the last local chieftan, who died between 1712 and 1717 , was preserved in a temple until 1780." Unquestionably this information originated in a letter of Dr. William Vans Murray, of Cambridge, Dorchester County, Maryland, addressed to Thomas Jefferson and dated September 18th, 1792, which is quoted in full by Dr. Frank G. Speck in an article dealing with the Nanticoke and Conoy Indians. ${ }^{43} \mathrm{Dr}$. Murray makes the following allusion to one of these mortuary temples:

"Wynicaco, the last king crowned of the Nanticoke tribe, he died at past 80 years since. His body was preserved and very formally kept in a Quacasumhouse-chio-ca-son house, 70 years dead." 44 In another place Dr. Murray refers thus to Wynicaco: "no king having succeeded their famous Winikake, who died 75 years since."

Of "Wynicaco" (Winnicaco, Winikake, Winogago, Wenegaco, Winnoughquarquo), whom Murray styles "the last king crowned of the Nanticoke tribe," there are several records. He was the son of Ababco, who, during most of the latter half of the seventeenth century, was king of the Choptank Indians inhabiting the lower Indian town on Choptank River. The Indians of this town, which was situated some little distance above Cambridge, Maryland, were specifically known to themselves as "Transquakines," but came to be known to the English as "Ababcos" or "Babcos" from the name of their king. Winnicaco made a treaty with Maryland May 18th, 1705.45 In this treaty he is styled "Winnoughquarquo, King of the Babcos." On March 9th, 1705 (Old Style; this was in March, 1706), with other Choptank chiefs and "great men," he

${ }^{43}$ The Nanticoke and Conoy Indians, with a Review of the Linguistic Material from Manuscript and Living Sources, Frank G. Speck, Papers of the Historical Society of Delaware, N.S. No. 1, 1927.

${ }^{44}$ Ibid., pp. 39-40.

${ }^{46}$ Maryland Archives, Vol. XXV, p. 442. 
deeded to $\mathrm{Wm}$. Seward a small tract of land within the Choptank reservation on Choptank River. ${ }^{46}$ This, so far as I can discover, is the last we hear of him. In 1722 Betty Caco, his daughter, was Queen of the "Ababco" Indians. ${ }^{47}$ Together with other Choptank Indians, on Sept. 9th, 1726, she conveyed to Edward Newton a parcel of land out of the Choptank reserve. ${ }^{48}$ In this deed she is described as "Betty Caco, Queen of the Ababco Indians, daughter and heir of Winnecaco late of Dorchester County, Deceased, who was Ruler and King of the afd. Ababco Indians." It is evident that there is nothing, in the records concerning Winnecaco which have come to our notice, to contradict Murray's statements as to the time of his death.

Dr. Murray does not take the trouble to distinguish between Nanticokes and Choptanks, although his information is concerned exclusively with the latter.

I do not find anywhere else direct reference to this most interesting burial custom of the Choptanks. I am therefore having recourse to land records and place-names for whatever corroboration of Dr. Murray's statement, however slight, may be found in them.

In a Proprietary rent-roll of Somerset County, Maryland, there is twice entered a tract of land containing five hundred acres, which was surveyed for James Wetherly on December 1, 1688, and is described as being situated in Nanticoke Hundred of the said county, on the south side of Nanticoke River. The exact location of this tract I have not as yet determined. In the first entry it is called "Quiakeson Neck," and there is no description as to location other than that already mentioned. The second entry reads as follows: "Nanticoke Hundred-500 (acres)-Quiankeson Neck-surv' for James Weatherly 1st of December, 1688 , lying on the so. side of Nanticoke River, beginning at a marked pine by a swamp near Indian Quiankeson houses." ${ }_{9}$ " Quiakeson Neck," otherwise called "Quiankeson Neck," was doubtless so named because it was the site of the "Indian Quiankeson houses." May not these "houses" have been mortuary temples for mummies similar to the "Quacasum-house" mentioned by Murray? The resemblances in these names are certainly striking enough to suggest this theory, and no other explanation of the meaning of "Indian Quiakeson houses" seems to be forthcoming.

What appears to be another instance of the occurrence of this Indian word is found among the land records of Dorchester County. An August 15th, 1761, a land commission was held on behalf of William Murray, in order to fix the bounds of a tract of land called "Ennalls' Outrange." ${ }_{50}$ It may be worth noting that this William Murray was Dr. Wm. Vans Murray's grandfather. In the preamble to the proceedings of this commission we are informed that the bounds of

${ }^{46}$ Dorchester County Records, Deed Book No. VI [Old], 1702-1716, folio 87.

${ }^{47}$ Maryland Archives, Vol. XXV, p. 393.

${ }^{48}$ Dorchester County Records, Deed Book VIII [Old], 1720-1732, folio 142.

${ }^{49}$ Somerset County rent-roll, Calvert Papers No. 885, pp. 146, 167; manuscript, Maryland Historical Society Library, Baltimore, Md.

${ }^{60}$ Dorchester County Records, Deed Book No. XVIII [Old], 1761-1763, folio 75. 
"Ennalls's Outrange" are known to depend "upon one of the Choptank Indians bounded trees standing in Cuiackason Swamp." Henry Ennalls testified that twenty years before he was shown a bounded white oak, since cut down, which "was commonly reported to be one of the Indian Bounders of the old original tract of the Indians land." The commissioners found that the aforesaid tree had stood "in a large swamp about $\frac{3}{4}$ of a mile to the eastward of Thomas Manning's dwelling plantation." Obviously they had reference to the swamp called Cuiackason Swamp.

Was the site of that "Quacasum-house" where, according to Murray, the mummy of "Whynicaco" lay in state for so many years, within the confines of "Cuiackason" Swamp? Possibly so. I think it more likely, however, that this "temple" was located in one of the Choptank towns, where it might the more easily be guarded against the intrusion of vandals. Moreover, the Indians, some time before Winnecaco's death, alienated that part of their reservation which lay in or adjacent to this swamp, If, as I deem it most likely, the name of this swamp has significance in connection with the subject which is under discussion, it doubtless harks back to a time when the homesteads of white settlers were few and far between in Dorchester County, excepting along the rivers. Beacuse of the interest which may attach to its name, it may not be out of place to tell what is known as to the location of Cuiackason Swamp, although its exact situation and identity have not been established. It should be remembered that courses and distances in old Maryland land patents and deeds are of ten erroneously stated, errors which must needs be corrected by later land commissions and resurveys. One of the causes of these mistakes is picturesquely set forth in a deposition taken in the year 1741 and entered among the land records of Dorchester County. ${ }^{51}$ The deponent, Edward Willoughby, aged seventy-one, quotes Mr. Smithson, a former surveyor of those parts, as saying: "There was great allowance given to People for that they went ashore at one place and rowed along: shore to another and Bounded Trees and sat their courses for fear of the Indians." With this in mind let us see what records tell us about the location of the swamp. A bounded tree of the Choptank Indian reservation stood within its confines. This tree was a boundary of "Ennalls' Outrange" In the year 1820 Charles Goldsborough obtained a warrant to resurvey "Ennalls' Outrange," together with four adjacent tracts or parts of tracts of land, including "Ricarton" and "The Indian Land alias Indian Survey" (i.e., part of the old Choptank reservation). ${ }^{62}$ Ricarton is a tract of land which antedates the reservation by several years. It occupies the northwest corner of the reservation and is that part of it on which Cambridge was laid out. The reservation was surveyed for the Choptank Indians by act of Maryland Assembly in the year 1669. The place of beginning is on Choptank River, about half a mile west of the mouth of Cambridge Creek and within the present limits of the town of Cambridge. The

51 Deed Book XIV, 1745-1753, folio 203.

${ }^{62}$ Land Office, Annapolis, Md., Eastern Shore Warrants, No. 12, 1818-1842, Warrant No. 1591 . 
reservation ran up the river to the mouth of Secretary's Creek, now called Warwick River, It was towards that end of it that the Indian towns were situated. It extended back into the woods from the river for a distance of three miles. Now, there is recorded at Cambridge, Maryland, a deed bearing date January 15 th, 1702/3, whereby Winacaco, "otherwise called Onocknatoone, Ruler and King of the Abapco's," conveyed to John Kirke a parcel of land "being the Lowermost part of a Tract of Land that my Predecessors Ababco, Dickwasine (Tequassino) and Harswamp (Hatsawap) had of the guift and grant of the Assembly of this Province." ${ }_{53}$ The land so conveyed begins "at the uppermost bounded tree of William Dorrington's freehold." This was the original beginning of the whole Indian reserve. From it the first line of the deed runs "south into the woods for length nine hundred and sixty perches (three miles) to a marked white oak." This marked white oak, in my opinion, was that same white oak tree, one of the Choptank Indians' bounded trees, which stood in Cuiackason Swamp. There is also recorded at Cambridge a deed dated August 13 th, 1704, whereby, for a valuable consideration, including forty pounds sterling and the three hundred and twenty matchcoats, Winacaco, otherwise called Onoocknatoon, and other Choptank chiefs conveyed to Thomas Ennalls a tract of land called Ennalls Purchase, containing three thousand six hundred and sixty acres, being part of their reservation on Choptank River. ${ }^{54}$ One of the boundaries called for in this deed is described as "a bounded white oak being the southernmost bounded Tree of sayd Land given by Act of Assembly as aforesaid and standing by the Road side that leads from the Towne of Yarmouth to the Towne of Cambridge neer to widdow Kings." The town of Yarmouth, or Little Yarmouth, seems to have been situated on the northern branch of Transquaking River, not far above the mouth of the Chicamacomico, in Dorchester County. It was a port of entry, but its use as such was discontinued in 1707. With these facts in mind it seems likely that the swamp called Cuiackason Swamp was situated within a mile and three-quarters of the present limits of Cambridge and to the southward of the town, and within threequarters of a mile to the eastward of the source of Little Blackwater River. Modern maps show no swamp at this place, but a heavy swamp begins about a mile southeast of it and extends for nearly four miles in the same direction towards Transquaking River.

Dr. Davidson alludes to an article by H. C. Mercer, published in 1897 and entitled: Exploration of an Indian Ossuary on Choptank River, Dorchester County, Maryland. He describes the site of Mercer's "exploration" as "a late historic one occupied by the Nanticoke until 1722, at which time the district was sold by the Indians to Europeans." I have not seen a copy of Mercer's article. Cambridge people appear to know of but one site on the Choptank which answers the description of an Indian ossuary. That site is among the sand banks of Sandy Hill, which is situated on the river about a mile below

${ }^{53}$ Dorchester County Records, Deed Book No. VI [Old], 1702-1716, folio 5.

${ }^{54}$ Dorchester County Records, Deed Book VI [Old], 1702-1716, folio 47. 
Cambridge, between Hambrook's Point and the mouth of Jenkins Creek. There is a tradition of excavations made there under scientific auspices thirty or forty years ago. Perhaps this has reference to Mercer's exploration. Later "diggings" have taken place under less happy circumstances. They culminated a few years ago, when quantities of sand were removed and many Indian artifacts are supposed to have found their way into the maw of a concrete-mixer. There are at present in private collections at Cambridge many objects of very fine workmanship which came from Sandy Hill. This place lies a mile down the river from the western limits of the Choptank reservation of 1669 and was never deeded by Indians to Europeans. Settlement of that part of Maryland by the English began in 1658. At that time the Choptank Indian towns would seem to have been three in number, the westernmost of which was situated on the river at a distance of three or four miles above the site of Cambridge. Just before the Maryland Assembly granted them their reservation, in 1669 , the three kings of the Choptanks, Ababco, Tequassino and Hatsawap, representing the three towns, requested that no English be allowed to settle on the south side of the Choptank above William Stevens Creek, which I would identify from land records as Jenkins Creek. Had this request been followed literally, Sandy Hill would have been included in the reservation. If this is the place where Mercer conducted his exploration, and if his deductions regarding the age of the site are correct, it must have been known to these Indians. To a surface collector like myself, the fine quality of the artifacts found at Sandy Hill is so striking and, for Maryland, so seemingly exotic, that I can not but believe that it was once a burial-place of considerable significance.

\author{
William B. Marye \\ Baltimore, \\ Maryland
}

\title{
The Archaeological Attitude
}

The following quotation from a book by Robert Henri: The Art Spirit, although intended for artists and students of art, applies equally well to students of archaeology:

"Every student should put down in some form or other his findings. All any man can hope to do is to add his fragment to the whole. No man can be final, but he can record his progress, and whatever he records is so much done in the thrashing out of the whole thing. What he leaves is so much for others to use as stones to step on or stones to avoid.

"The student is not an isolated force. He belongs to a great brotherhood, bears great kinship to his kind. He takes and he gives. He benefits by taking and he benefits by giving."

\author{
Herbert W. KuhM \\ President, Wisconsin Archeological Society, \\ Milwaukee, Wisconsin
}

